\title{
Long Term Influence of Organic and Inorganic Fertilization on Soil Enzyme Activities in Calcareous Soil under Rice Wheat Cropping System
}

\author{
Praveen Kumar Bharti ${ }^{1}$, Amit Kumar Pandey ${ }^{2 *}$ and Ashutosh Singh ${ }^{1}$
}

${ }^{1}$ Dr. Rajendra Prasad Central Agricultural University, Pusa, Samastipur-848125 (Bihar), India

${ }^{2}$ Department of Soil Science and Agricultural Chemistry, Bihar Agricultural University, Sabour, Bhagalpur-813210 (Bihar), India

*Corresponding author

\section{A B S T R A C T}

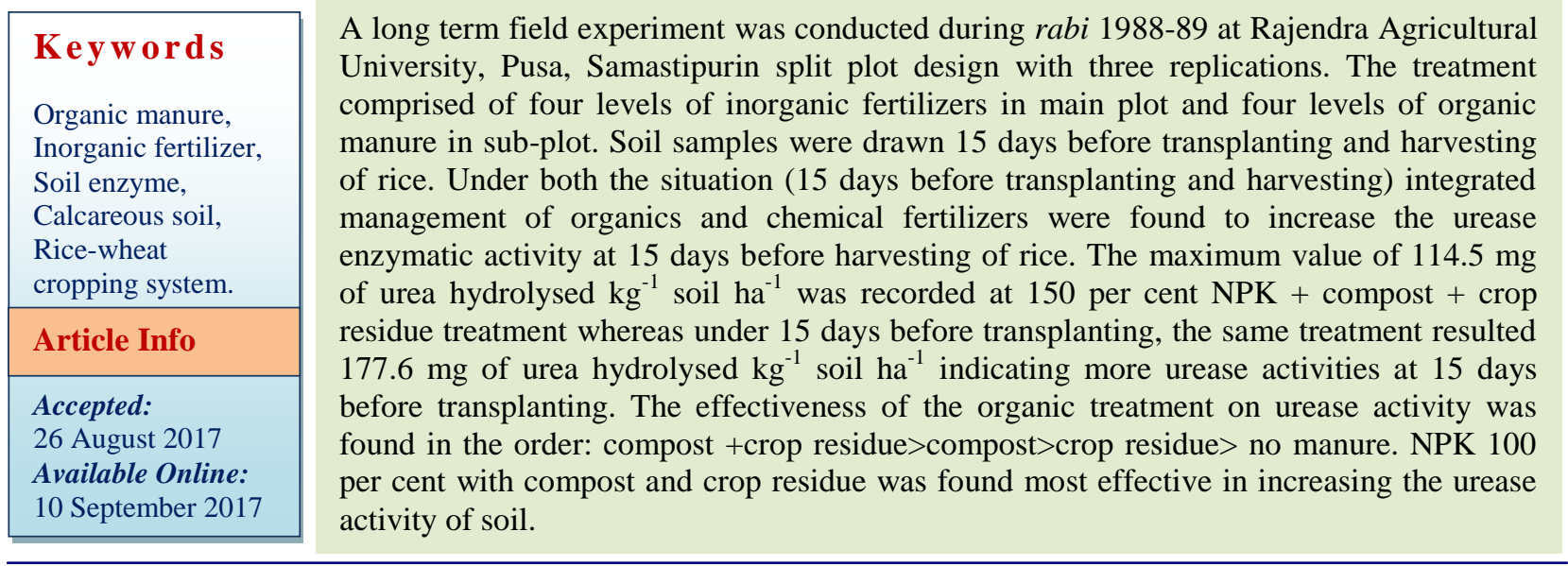

\section{Introduction}

Compost and crop residue plays and important role in improving the physical, chemical and biological properties of soil. Soil enzymes are considered to be the contributor of soil microbial activity as well as soil quality in soil environment (Liu et al., 2010). It also plays an important role in organic matter decomposition and in the dynamics of nutrient transformation in soil. Some enzymes only facilitates the breakdown of organic matter e.g. hydrolase, glucosidase while others are involved in nutrient mineralization e.g. amidase, urease etc. Enzyme activities are potential indicators of soil quality because they are sensitive, rapid and inexpensive representatives of the potential metabolic activity of the soil (Liang et al., 2014).

Rice wheat cropping system is an important cropping system of North Bihar. But a negative or stagnant growth in total productivity factor was recorded over a period of time in 94 districts in the rice-wheat production system of the Indo-Gangetic Plains (Raman, 2005). Such decreasing might be due to depletion of soil nutrients and loss of soil fertility. Restoring of soil fertility with 
the addition of synthetic fertilizer is no more considered as an ideal approach. Supplementation of synthetic fertilizer with organic residue from plant and animal sources are also advocated. But such supplementation has its own limitations. The ideal approach will be the strengthening of soil microbial activity. Therefore, complementary use of organic and inorganic fertilizers and their management for efficient and economic use of fertilizers and maintenance of soil enzymatic activity is very important. Keeping in view of these facts, research programme was formulated to assess the effect of long term application of compost, crop residue and inorganic fertilizer on soil enzyme (urease) activity.

\section{Materials and Methods}

A long term field experiment was started during rabi 1988-89 in calcareous soil with rice-wheat sequence. The details of the materials used and method adopted for carrying out the present study are described as below. The experimental site is located at $25^{\circ} 59^{\prime}$ North latitude and $85^{\circ} 48^{\prime}$ East longitude with an altitude of 52.92 meters above mean sea level. The climate of the experimental area is sub-tropical with a mean annual precipitation of $1270 \mathrm{~mm}$ and mean annual temperature of $25.3^{\circ} \mathrm{C}$. The crop reported in this report was $34^{\text {th }}$ crop of rice (cv. Rajshree) in kharif season, 2005 with continuous application of compost @ 10 tha $^{-1}$ and/or crop residue of the respective plot alone or in combination with different levels of NPK. The experiment was conducted in a split plot design with four levels of NPK namely; No NPK, 50\% NPK, 100\% NPK\& $150 \%$ NPK in the main treatment and organic sources such as no manure, compost, crop residue and compost + crop residue in subplot treatment. The treatments were replicated thrice. The recommended $\mathrm{N}, \mathrm{P}_{2} \mathrm{O}_{5}$ and $\mathrm{K}_{2} \mathrm{O}$ doses were 120,60 and $40 \mathrm{~kg} \mathrm{ha}^{-1}$.The physio-chemical properties of surface soil (0-
$15 \mathrm{~cm}$ ) analysed at the start of the experiment are presented in table 1 . The average nutrient composition of compost and wheat straw applied in the experiment are presented in table 2. Urease activity was measured following the method of Tabatabai and Bremer, 1972. Five gram of soil was incubated with $9.0 \mathrm{ml}$ THAM buffer, $0.2 \mathrm{ml}$ toluene and $1 \mathrm{ml}$ of $0.2 \%$ of urea solution at $37^{\circ} \mathrm{C}$ for 2 hours. Then $50 \mathrm{ml} \mathrm{KCl} \mathrm{AgSO}_{4}$ solution was added, shaking was done for 30 minutes and soil suspension was filtered. Taking $20 \mathrm{ml}$ of aliquot from filtrate, $\mathrm{NH}_{4}-\mathrm{N}$ was determined by steam distillation method (Keeney and Nelson, 1982).

\section{Results and Discussion}

Fifteen (15) days before transplanting total urease activity of soil was significantly influenced by application of organic manure and chemical fertilizers over control (Table 3 ). The total urease activity varied from 92.5 to $117.6 \mathrm{mg}$ of urea hydrolysed $\mathrm{kg}^{-1}$ soil ha ${ }^{-1}$ in different treatments. The maximum activity was recorded with compost + crop residue (110.2 mg of urea hydrolysed $\mathrm{kg}^{-1}$ soil ha ${ }^{-1}$ ) treatment which was significantly higher followed by compost (107.7 $\mathrm{mg}$ of urea hydrolysed $\mathrm{kg}^{-1}$ soil ha ${ }^{-1}$ ), crop residue (106.5 $\mathrm{mg}$ of urea hydrolysed $\mathrm{kg}^{-1}$ soil ha ${ }^{-1}$ ) and no manure $\left(102.6 \mathrm{mg}\right.$ of urea hydrolysed $\mathrm{kg}^{-1}$ soil $\mathrm{ha}^{-1}$ soil $\left.\mathrm{ha}^{-1}\right)$ treatments, respectively. This can be attributed to greater input of root biomass due to better crop productivity (Liu et al., 2010).

The urease activity increased by $4.99,3.80$ and 7.40 percent over control (102.6 mg of urea hydrolysed $\mathrm{kg}^{-1}$ soil ha ${ }^{-1}$ soil ha ${ }^{-1}$ ) with the addition of compost, crop residue and compost + crop residue, respectively, whereas, inorganic treatments received 50, 100 and 150 percent NPK increased the total urease activity by 5.29, 12.62 and 16.90 percent over control $(98.2 \mathrm{mg}$ of urea hydrolysed $\mathrm{kg}^{-1}$ soil ha ${ }^{-1}$ ), respectively. 
Table.1 Physio-chemical properties of soil of experimental plot

\begin{tabular}{|c|l|c|}
\hline Sl. No. & Particulars & Value obtained \\
\hline 1. & Sand $(\%)$ & 46.85 \\
\hline 2. & Silt $(\%)$ & 41.35 \\
\hline 3. & Clay (\%) & 11.8 \\
\hline 4. & Texture & Sandy loam \\
\hline $\mathbf{5 .}$ & pH $(1: 2$ Soil: water $)$ & 8.5 \\
\hline 6. & Electrical conductivity $\left(\mathrm{dSm}^{-1}\right)$ at $25^{\circ} \mathrm{C}$ & 0.80 \\
\hline $\mathbf{7 .}$ & Organic carbon $(\%)$ & 0.35 \\
\hline $\mathbf{8 .}$ & Available $\mathrm{N}\left(\mathrm{kg} \mathrm{ha}^{-1}\right)$ & 219.0 \\
\hline $\mathbf{9 .}$ & Available $\mathrm{P}_{2} \mathrm{O}_{5}\left(\mathrm{~kg} \mathrm{ha}^{-1}\right)$ & 17.5 \\
\hline $\mathbf{1 0 .}$ & Available $\mathrm{K}_{2} \mathrm{O}\left(\mathrm{kg} \mathrm{ha}^{-1}\right)$ & 114.2 \\
\hline $\mathbf{1 1 .}$ & Free $\mathrm{CaCO}_{3}(\%)$ & 21.6 \\
\hline
\end{tabular}

Table.2 Mean nutrient composition of various organic manures used

\begin{tabular}{|l|c|c|c|c|c|}
\hline $\begin{array}{l}\text { Organic } \\
\text { manure }\end{array}$ & $\begin{array}{c}\text { Organic } \\
\text { Carbon (\%) }\end{array}$ & $\mathbf{N ~ ( \% )}$ & $\mathbf{P}(\boldsymbol{\%})$ & $\mathbf{K ~ ( \% )}$ & $\mathbf{C : N}$ \\
\hline Compost & 38.2 & 1.2 & 0.92 & 1.83 & 31.6 \\
\hline Wheat straw & 50.9 & 0.5 & 0.07 & 1.69 & 101.8 \\
\hline
\end{tabular}

Table.3 Influence of organic and inorganic fertilizers on urease activity ( $\mathrm{mg}$ of urea hydrolysed $\mathrm{Kg}^{-1}$ soil ha $\left.{ }^{-1}\right)$ in rice soil ( $34^{\text {th }}$ crop) under rice-wheat cropping system

\begin{tabular}{|c|c|c|c|c|c|c|c|c|c|c|}
\hline \multirow{3}{*}{$\begin{array}{l}\text { Fertilizer } \\
\text { Level }\end{array}$} & \multicolumn{10}{|c|}{ Organics Sources } \\
\hline & \multicolumn{5}{|c|}{15 days before harvesting of rice } & \multicolumn{5}{|c|}{15 days after harvesting of rice } \\
\hline & $\begin{array}{c}\text { No } \\
\text { Manure }\end{array}$ & Compost & $\begin{array}{c}\text { Crop } \\
\text { Residue }\end{array}$ & $\begin{array}{c}\text { Compost }+ \\
\text { Crop Residue }\end{array}$ & Mean & $\begin{array}{c}\text { No } \\
\text { Manure }\end{array}$ & Compost & $\begin{array}{c}\text { Crop } \\
\text { Residue }\end{array}$ & $\begin{array}{c}\text { Compost }+ \\
\text { Crop Residue }\end{array}$ & Mean \\
\hline No NPK & 92.5 & 99.2 & 98.5 & 102.8 & 98.2 & 89.2 & 97.6 & 96.8 & 98.2 & 95.4 \\
\hline $50 \%$ NPK & 97.3 & 105.4 & 103.8 & 107.2 & 103.4 & 95.6 & 101.8 & 100.4 & 106.5 & 101.0 \\
\hline $100 \% \mathrm{NPK}$ & 108.4 & 111.2 & 109.6 & 113.4 & 110.6 & 99.4 & 105.6 & 104.8 & 111.4 & 105.3 \\
\hline $150 \% \mathrm{NPK}$ & 112.3 & 115.3 & 114.2 & 117.6 & 114.8 & 103.8 & 107.2 & 107.6 & 114.5 & 108.2 \\
\hline Mean & 102.6 & 107.6 & 106.5 & 110.2 & & 97.6 & 103.0 & 102.4 & 107.6 & \\
\hline Sources & & S.Em \pm & & $\mathrm{CD}$ at $5 \%$ & & & S.Em \pm & & CD at $5 \%$ & \\
\hline Fertilizer $(\mathrm{F})$ & & 0.85 & & 2.96 & & & 0.84 & & 2.93 & \\
\hline Organics $(\mathrm{M})$ & & 0.86 & & 2.51 & & & 0.94 & & 2.75 & \\
\hline $\mathrm{F} \times \mathrm{M}$ & & 1.72 & & NS & & & 1.84 & & NS & \\
\hline
\end{tabular}

Furthers it was observed that under 15 days before harvesting, the incorporation of compost, crop residue and compost + crop residue resulted higher mean urease activity over control in order 97.7 to $103.0 \mathrm{mg}$ of urea hydrolysed $\mathrm{kg}^{-1}$ soil ha-1, 97.7 to $102.4 \mathrm{mg}$ of urea hydrolysed $\mathrm{kg}^{-1}$ soil $\mathrm{ha}^{-1}$ and 97.7 to $107.6 \mathrm{mg}$ of urea hydrolysed $\mathrm{kg}^{-1}$ soil ha ${ }^{-1}$, respectively. The percent increase was to a tune of $5.42,4.81$ and 10.13 more over control $\left(97.7 \mathrm{mg}\right.$ of urea hydrolysed $\mathrm{kg}^{-1}$ soil $\left.\mathrm{ha}^{-1}\right)$ at compost, crop residue and compost + crop residue, respectively. Under same situation application of mineral fertilizers also exerted significant increase in the mean value of urease activity. It ranged from 95.4 to $108.2 \mathrm{mg}$ urea hydrolysed $\mathrm{kg}^{-1}$ soil ha ${ }^{-1}$ with increased levels of fertilizers. The percent 
increase was 3.87, 10.37 and 13.41 over control $\left(95.4 \mathrm{mg}\right.$ of urea hydrolysed $\mathrm{kg}^{-1}$ soil $\mathrm{ha}^{-1}$ ) at 50, 100 and 150 percent NPK application, respectively. A perusal of the data in table 3 clearly indicated that levels of fertilizer and different sources of organic manure significantly influenced the urease activity under 15 days before transplanting and harvesting. Application of balanced amount of nutrients and manures improved the MBC status of soil which corresponds to higher enzyme activities (Mandal et al., 2007). But decreases in urease activity at all treatments were observed under 15 days before harvesting as compared to 15 days before transplanting. The soil enzyme urease was positively related to FYM application Hasan (2000). The increase in urease activity might be due to higher microbial population and their activity in organic and inorganic treatment. The soil urease is increased by urea concentration (Pal and Chhonka, 1979). The critical examination of data revealed that 150 percent NPK with compost + crop residue contributed higher urease activity in the soil which was almost similar to 100 percent NPK + compost + crop residue. Thus, 100 percent NPK + compost + crop residue may be the best for economic treatment. Increase in urease activity (Raju et al., 2013 and Lakshmi et al., 2014) with addition of organic manure with or without mineral fertilizer is well documented as we have received same set of result.

Over and above the effects of chemical fertilizers and organic manure either alone or in combination enhanced enzymatic activities in the soil. The integrated effect of inorganic and organic exerted more beneficial on soil enzymatic activities.

\section{Acknowledgement}

The authors are thankful to the Director Research of the Experiment Station, R.A.U.
Pusa, Samastipur, Bihar for provide the financial assistance to carry out the present investigation.

\section{References}

Hasan, H.A.H., 2000. Ureolytic microorganism and soil fertility. Communication in Soil Science and Plant Analysis31: 15-16.

Keeney, D.R., and Nelson, D.W. 1982. Nitrogen-inorganic forms. In: Page, A.L.; Miller, R.H. and Keeney, D.R. (Eds.) methods of soil analysis part-2. Soil Science Society of America, Madison Wisconsin pp 643-698.

Lakshmi, S. R., Rao, P. C., Sreelatha, T., Padmaja, G., Madhavi, M. and Rao, P.V. 2014. Biochemical changes in submerged rice soil amended with different Vermicompost under integrated nutrient management. Journal of Indian Society of Soil Science62: 131-139.

Liang, Q., Chen, H., Gong, Y., Yang, H., Fan, M. and Kuzyakov, Y. 2014. Effect of 15 years of manures and mineral fertilizers on enzyme activity in particles size fractions in a North China Plain soil. European Journal of Soil Biology60: 112-119.

Liu, E., Yan, C., Mei, X., He,W., Bing, H.,S. and Ding, L. 2010. Long term effect of chemical fertilizer, straw and manure on soil chemical and biological properties in Northwest China. Geoderma158: 173-180.

Mandal, A., Patra, A. K., Singh, D., Swarup, A. and Masto R.E. 2007. Effect of long term application of manure and fertilizer on biological and biochemical activities in soil during crop development stages. Bioresource Technology98:3585-3592.

Pal, S.S., and Jat, M. L. 2004. Enhanced decomposition of rice straw and its 
effect on soil health and crop yield in rice-wheat cropping system in an ustochrept of Indo-Gangetic Plain. Indian Journal of Agriculture Science 74: 409-414.

Raju, B., Rao, P. C., Reddy, A.P. and Padmavati, P. 2013. Effect of various INM on yield, urease and dehydrogenase activity in safflower. Helix Journal6:405-408.

Raman, K.V., 2005. Sustaining soil fertility. The Hindu Survey of Indian Agriculture: 165-167.

Tabatabai, M.A., and Bremner, J.M. 1972. Assay of urease activity in soil. Soil Biology and Biochemistry4: 479-487.

\section{How to cite this article:}

Praveen Kumar Bharti, Amit Kumar Pandey and Ashutosh Singh. 2017. Long Term Influence of Organic and Inorganic Fertilization on Soil Enzyme Activities in Calcareous Soil under Rice Wheat Cropping System. Int.J.Curr.Microbiol.App.Sci. 6(9): 2868-2872. doi: https://doi.org/10.20546/ijcmas.2017.609.352 